\title{
Effect of Genistein on Heat Shock Protein 47 and Collagen Type IV in Diabetic Rat
}

\author{
Putri Dafriani $i^{1, *}$, Nur Indrawati Lipoeto ${ }^{2}$, Yanwirasti $^{2}$, Amri Bakhtiar $^{3}$ and Roza Marlinda ${ }^{1}$ \\ ${ }^{1}$ Sekolah Tinggi Kesehatan Syedza Saintika, Padang, Indonesia \\ ${ }^{2}$ Faculty of Medicine, Andalas University, Padang, Indonesia \\ ${ }^{3}$ Faculty of Pharmacy, Andalas University, Padang, Indonesia
}

\begin{abstract}
Diabetes nephropathy (DN) is one of the most common complication in Diabetes Mellitus (DM). DN is an inflammatory process which involved immune cells and effect of genistein prevent this mechanism. However, the effects on HSP 47 and collagen type IV are not yet verified. The purpose of this study was to investigate whether the genistein can suppress HSP 47 and collagen type IV.

This study is experimental design used 25 rats. Rats were divided into five groups; normal group, hyperglycemia group, hyperglycemia by administering genistein $0.5 \mathrm{mg} / \mathrm{kgw}, 1 \mathrm{mg} / \mathrm{kgw}$, and $2 \mathrm{mg} / \mathrm{kg}$. Streptozotocin induced $65 \mathrm{mg} / \mathrm{kg}$ administered intraperitoneal. Treatment duration is 4 weeks. After 4 weeks of blood was collected via the orbital vein and examined the levels of HSP 47 then rats' kidneys were taken to see the levels of collagen type IV.

The average levels of HSP 47 in non diabetic control group was $1.7982 \mathrm{ng} / \mathrm{ml}$, diabetic control $7.9424 \mathrm{ng} / \mathrm{ml}$, STZ; G $0.5 \mathrm{mg} / \mathrm{kgw} 5.4192 \mathrm{ng} / \mathrm{ml}$, STZ; G $1 \mathrm{mg} / \mathrm{kgw} 3.1152 \mathrm{ng} / \mathrm{ml}$ and STZ; G $2 \mathrm{mg} / \mathrm{kgw} 1.849 \mathrm{ng} / \mathrm{ml}$, with p value $0.000(p<0.05)$. While Type IV Collagen in non diabetic group was $10.006 \mathrm{ng} / \mathrm{ml}$, diabetic group $26.864 \mathrm{ng} / \mathrm{ml}$, STZ: G $0.5 \mathrm{mg} / \mathrm{kgw} 21.426 \mathrm{ng} / \mathrm{ml}$, STZ; G $1 \mathrm{mg} / \mathrm{kgw} 17.352 \mathrm{ng} / \mathrm{ml}$ and STZ; G $2 \mathrm{mg} / \mathrm{kgw} 13.436 \mathrm{ng} / \mathrm{ml}$ with $\mathrm{p}$ value $0.000(\mathrm{p}<0.05)$.
\end{abstract}

Administer the genistein can reduce levels of HSP 47 and collagen type IV in diabetic rats. Genistein can reduce fibrotic mediators induced by NFkB and MAPK signaling by inhibiting the tyrosine kinase protein activation.

Keywords: Genistein, HSP 47 and Type IV Collagen.

\section{INTRODUCTION}

Diabetes mellitus (DM) is one of the most important health problems worldwide. International Diabetes Federation estimated the number of adult people living with diabetics will rise from 285 million in 2010 to 439 million in 2030. Diabetic nephropathy (DN) is seriouly diabetic complications. Diabetic nephropathy is a major cause of end stage renal disease [1]. Diabetic nephropathy occurs $30-40 \%$ of all cases of diabetes [2]. Diabetic nephropathy is characterized by the occurrence of deformation of kidney structure, expansion of mesangial cells and thickening of the glomerular membrane [3].

Hyperglycemia initiated a pathological condition. Hyperglycemia activates polyol pathway which then activates protein kinase $C$ (PKC), and formation of advanced glycation end products (AGEs). AGEs activates macrophages to produce proinflammatory cytokines [4]. Activation of NFKB plays an important role in the inflammatory process because it is a transcription factor of pro-inflammatory genes.

*Address correspondence to this author at the Sekolah Tinggi Kesehatan Syedza Saintika, Padang, Indonesia; Tel: +62751442699; Fax: +62751442699; E-mail: putridafrianiabd@gmail.com
Oxidative stress can increase proinflammatory cytokines through several mechanisms, presence of free oxygen, the role of second messengers, activation of the transcription factor kappa beta (NFkB) and activator protein-1 (AP-1). Control of inflammatory factors will inhibit the process of sustainable fibrosis [5].

Oksidative Stress causes changes in transcription factors genes encoding cytokines, growth factors and proteins that make up the extracellular matrix [6]. In diabetic rat kidneys, Nuclear factor kappa beta activates mesangial cells [7]. NFKB also stimulates fast transcription factor genes endothelin-1 (ET-1), vascular cell adhesion molecule-1 (VCAM-1), intercellular adhesion molecule-1 (ICAM-1), interleukine 6, interleukin 1 and tumor necrosis a (TNF- $\alpha$ ), which increases the development of diabetic nephropathy. TNF- $\alpha$ and IL-1 causes enhanced expression of chemotactic factors (MCP-1), stimulates the kidney cells produce growth factors (TGF- $\beta$, CTGF, VEGF), increasing the permeability of vascular endothelium and stimulate cell proliferation mesangial cells and improve the formation of extracellular matrix [8].

Activation profibrotic cytokines such as (TGF- $\beta$ ) in renal tissue causes fibrosis in the kidney. Fibrosis is 
accumulation extracellular matrix. The dominant extracellular matrix in the kidney is collagen type IV [9]. The sintesis of collagen type IV is mediated by heat shock protein (HSP) 47 [10]. Heat shock protein (HSP) 47 is a collagen-binding glycoprotein that is located within the endoplasmic reticulum. HSP 47 important in the development of fibrosis by preventing the misfolding of collagen [11]. Increased expression of HSP 47 was associated with increased collagen accumulation in renal fibrosis [12]. HSP 47 expression is increased in kidney of diabetic rats induced by streptozotocin [13]. Animal studies that fibrosis obtained by lowering the levels of HSP 47 can reduce the production of collagen and progression of fibrosis [14].

The use of herbs and natural medicines has become an alternative in DM and DN. One of them is soy. Beside as an anti diabetic, soy is one of source of nutrition for humans. Most of Asian people use it as a food ingredient [15].

Isoflavones is one of flavanoid that have effect as antioxidant and inhibitor tyrosine kinase. The Soy of isoflavone consist genistein, daidzein and glycetein.Genistein (4',5,7-trihydroxyisoflavone)is one of the major soy isoflavones [16]. Genistein has a very interesting biological activity. Genistein can decrease the activity of genes that regulate cell proliferation, cell cycle, inducing apoptosis, inhibiting the activation of NF-KB and have antioxidant effects [17].

The positive effect of genistein on diabetic renal are still insufficiently presented in the literature, so the purpose of this study is to investigated whether the genistein can reduce fibrosis by decreasing HSP 47 and collagen type IV.

\section{MATERIAL AND METHODS}

\section{Chemicals}

Genistein and streptozotocin (STZ) were purchased from Sigma Aldrich. Kits for the assay of HSP 47 and collagen type IV were purchased from elabscience. The chemicals and solvents used in the study were purchased from farmacology laboratory Andalas University, Indonesia.

\section{Diet}

Diet of non diabetic groupis starch and diabetic groups is genistein. Genistein is given by oral use stomach tube at a dose of $0.5 \mathrm{mg} / \mathrm{kgw} /$ day, 1 $\mathrm{mg} / \mathrm{kgw} /$ day, $2 \mathrm{mg} / \mathrm{kgw} /$ day. $100 \mathrm{mg}$ of genistein dissolved in $100 \mathrm{ml}(1 \mathrm{mg} / 1 \mathrm{ml})$. Itwas gave for 30 days.

\section{Animals}

At the beginning of the experiment, Male wistar rats weighing between 150 and $200 \mathrm{~g}$ were purchased from farmacology Laboratory Animal Research (Padang, Indonesia). The animals were all individually housed in stainless steel cages in an air-conditioned room with controlled temperature $\left(20-22{ }^{\circ} \mathrm{C}\right)$ and automatic lighting (alternation 12-h periods of light and dark) and fed an AIN-93 [18]. The experimental procedures were done according to the guidelines of Committee for the Purpose of Control and Supervision of Experiments on Animals (CPCSEA) and approved by the Institutional Ethical Committee of Animal Care, Andalas university, Indonesia (NO: 104/KEP/FK/2015).

\section{Experimental Design}

The animals were divided into two groups: a nondiabetic control and a diabetic group. Diabetes was induced by a single injection of STZ $(50 \mathrm{mg} / \mathrm{kgw}$; Sigma, USA). STZ dissolved in a $0.1 \mathrm{~mol} / \mathrm{L}$ citrate buffer ( $\mathrm{pH}$ 4.5) and then it injected into the intraperitonium. The control rats were only injected with the citrate buffer. Diabetes was confirmed in the STZtreated rats by measuring the fasting blood glucose concentration 48-h post-injection. The rats with blood glucose level above $350 \mathrm{mg} / \mathrm{dL}$ were considered to be diabetic and were used in the experiment. The diabetic rats were randomly divided into four sub-groups, diabetic controls (STZ), diabetic rats given genistein (STZ-G; $0.5 \mathrm{mg} / \mathrm{kgw}$ ), (STZ; $1 \mathrm{mg} / \mathrm{kgw}$ ) and (STZ-; 2 $\mathrm{mg} / \mathrm{kgw}$ ). In this study, 25 rats were used (five controls and 20 diabetic).

After 30 days of treatment, the rats were anesthetized with ether following a 16-h fast. Blood samples were taken from the abdominal aorta using heparin-coated syringes for plasma and regular syringes for serum. Plasma and serum were obtained by centrifuging the blood at $3000 \mathrm{rpm}$ for $15 \mathrm{~min}$ at 4 ${ }^{\circ} \mathrm{C}$. The kidneys were removed and rinsed with physiological saline. All samples were stored at $-70{ }^{\circ} \mathrm{C}$ until analyzed.

\section{Assay of Inflammatory Markers}

\section{HSP 47 and Collagen Type IV}

Add Sample: Add 100 $\mu \mathrm{L}$ of Standard, Blank, or Sample per well. The blank well is added with Reference Standard \& Sample diluent. Solutions are added to the bottom of micro ELISA plate well, avoid inside wall touching and foaming as possible. Mix it gently. Cover the plate with sealer we provided. 
Incubate for 90 minutes at $37^{\circ} \mathrm{C}$. Biotinylated Detection $\mathrm{Ab}$ : Remove the liquid of each well, don't wash. Immediately add $100 \mu \mathrm{L}$ of Biotinylated Detection $\mathrm{Ab}$ working solution to each well. Cover with the Plate sealer. Gently tap the plate to ensure thorough mixing. Incubate for 1 hour at $37^{\circ} \mathrm{C}$.Wash: Aspirate each well and wash, repeating the process three times. Wash by filling each well with Wash Buffer (approximately $350 \mu \mathrm{L}$ ) (a squirt bottle, multi-channel pipette, manifold dispenser or automated washer are needed). Complete removal of liquid at each step is essential. After the last wash, remove remained Wash Buffer by aspirating or decanting. Invert the plate and pat it against thick clean absorbent paper. HRP Conjugate: Add $100 \mu \mathrm{L}$ of HRP Conjugate working solution to each well. Cover with the Plate sealer. Incubate for 30 minutes at $37^{\circ} \mathrm{C}$. Wash: Repeat the wash process for five times as conducted in step 3. Substrate: Add 90 L of Substrate Solution to each well. Cover with a new Plate sealer. Incubate for about 15 minutes at $37^{\circ} \mathrm{C}$. Protect the plate from light. The reaction time can be shortened or extended according to the actual color change, but not more than 30minutes. When apparent gradient appeared in standard wells, user should terminate the reaction. Stop: Add $50 \mu$ Lof Stop Solution to each well. Then, the color turns to yellow immediately. The order to add stop solution should be the same as the substrate solution. OD Measurement: Determine the optical density (OD value) of each well at once, using a micro-plate reader set to $450 \mathrm{~nm}$. User should open the micro-plate reader in advance, preheat the instrument, and set the testing parameters. After experiment, put all the unused reagents back into the refrigerator according to the specified storage temperature respectively until their expiry.

\section{Statistical Analysis}

All data are presented as the mean \pm SE. The data were evaluated by a one-way ANOVA using the SPSS program, and the differences between the means assessed using posthoc bonferroni. Statistical significance was considered at $p<0.05$.

\section{RESULTS}

\section{Effect of Genistein on HSP 47}

ANOVA test result found significant difference in average levels of HSP 47 between diabetic group and non diabetic control group. The average levels of HSP 47 in non diabetic control group was 1.7982 $\mathrm{ng} / \mathrm{ml}$, while diabetic control $7.9424 \mathrm{ng} / \mathrm{ml}$, STZ; G $0.5 \mathrm{mg} / \mathrm{kgw} 5.4192 \mathrm{ng} / \mathrm{ml}$, STZ; G $1 \mathrm{mg} / \mathrm{kgw}$
$3.1152 \mathrm{ng} / \mathrm{ml}$ and STZ; G $2 \mathrm{mg} / \mathrm{kgw} 1.849 \mathrm{ng} / \mathrm{ml}$, with $p$ value of $0.000(p<0.05)$. This means that there is positive effect of genistein on the levels of HSP 47. Post hoc Bonferroni were used to see the significance diffence between treatment groups. There are no significant differences between STZ group with STZ group G $0.5 \mathrm{mg} / \mathrm{kgw}$, whereas there are significant differences between the STZ group with STZ group G $1 \mathrm{mg} / \mathrm{kgw}$ and STZ G $2 \mathrm{mg} / \mathrm{kgw}$.

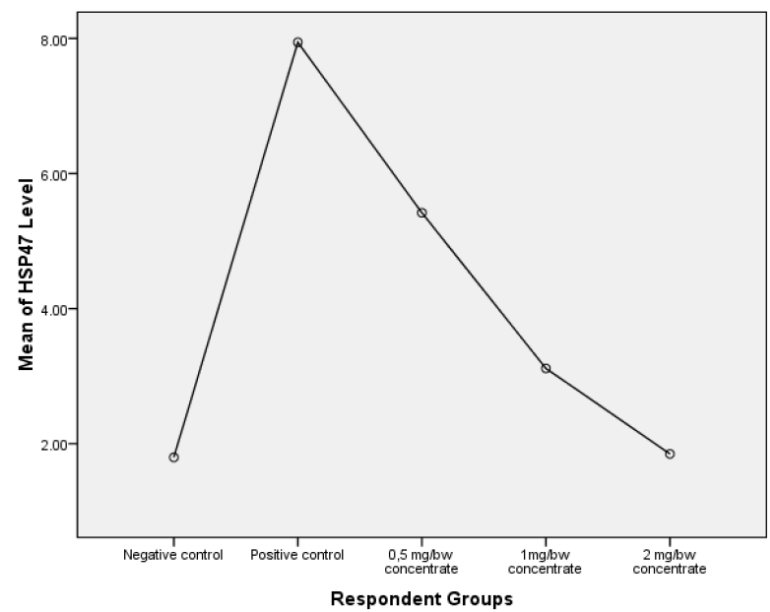

Figure 1: Mean of HSP 47 level between non diabetic control group and diabetic group.

\section{Effect of Genistein on Collagen Type IV}

There is significant differences in average levels of Type IV Collagen between non diabetic control group and diabetic group. The average levels of Type IV Collagen in non diabetic group was $10.006 \mathrm{ng} / \mathrm{ml}$, diabetic group $26.864 \mathrm{ng} / \mathrm{ml}$, STZ: G $0.5 \mathrm{mg} / \mathrm{kgw}$ $21.426 \mathrm{ng} / \mathrm{ml}$, STZ; G $1 \mathrm{mg} / \mathrm{kgw} 17.352 \mathrm{ng} / \mathrm{ml}$ and $\mathrm{STZ} ; \mathrm{G} 2 \mathrm{mg} / \mathrm{kgw} 13.436 \mathrm{ng} / \mathrm{ml}$ with $\mathrm{p}$ value 0.000 $(p<0.05)$. This means that there is the effect of genistein on the levels of type IV collagen. To see the difference among the treatment groups, Post Hoc Bonferroni test were used. There are significant differences among STZ group with STZ G 0.5 $\mathrm{mg} / \mathrm{kgw}, \mathrm{STZ} \mathrm{G} 1 \mathrm{mg} / \mathrm{kgw}$ and STZ G $2 \mathrm{mg} / \mathrm{kgw}$.

\section{DISCUSSIONS}

\section{Effect of Genistein on Levels of HSP 47}

Levels of HSP $47 \mathrm{STZ}$ group $7.9424 \mathrm{ng} / \mathrm{ml}$ higher than the levels of HSP 47 non diabetic group 1.7982 $\mathrm{ng} / \mathrm{ml}$. This suggests that hyperglycemia can cause elevated levels of HSP 47 . The chemical reaction between sugar products with a protein that occurs over several days to several weeks to produce irreversible protein derivative called AGE (Advanced Glycation End Products). Derivatives This causes thickening of 


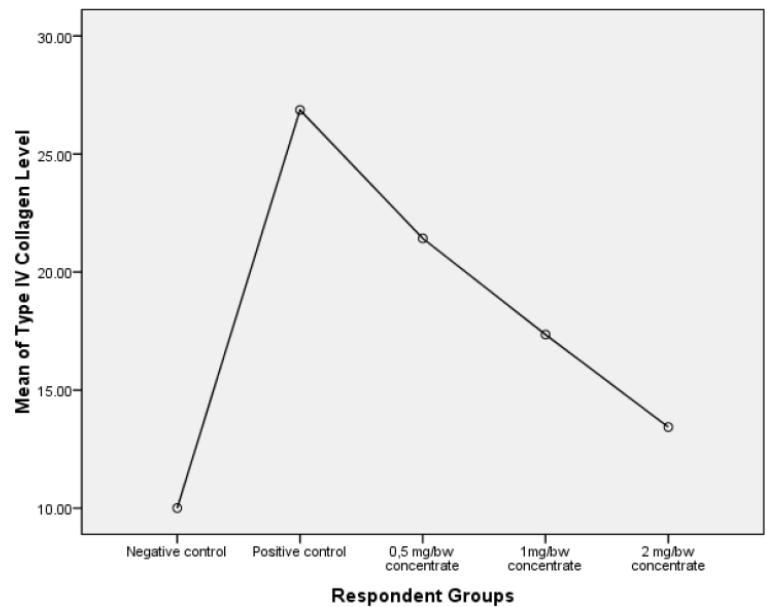

Figure 2: Mean of collagen type IV level between non diabetic control group and diabetic group.

collagen and endothelium, accelerated atherosclerosis, glomerular dysfunction, reduced formation of nitric oxide and alter the composition and structure of the extracellular matrix [19].

The formation of AGE also stimulate excessive secretion of anti-growth factors such as insulin-like growth factor 1 and transforming growth factor beta which causes decreased glomerular surface area for filtration. AGEs stimulate HSP 47 through increase in TGF- $\beta$. AGE also increased the expression of HSP 47 mRNA and collagen type IV. Giving AGE inhibitors can inhibit the buildup of matrix ekstrasluler [20].

Fibrogenic factors such as transforming growth factor (TGF) $-\beta 1$ generated by the activation and changes the phenotype of cells resident and inflammatory cells that cause disease in humans and animals fibrosis experiments that subsequently increases the production of collagen. TGF- $\beta 1$ affect the extracellular matrix. HSP47 plays an important role in fibrosis enhanced by increasing regulation of transcription factors to collagen. Thus, TGF- $\beta 1$ can stimulate the expression of HSP47 [12].

The current study found genistein administration at a dose of $0.5 \mathrm{mg} / \mathrm{kgw}(\mathrm{p}=0.001), 1 \mathrm{mg} / \mathrm{kgw}(\mathrm{p}=$ $0.000)$ and $2 \mathrm{mg} / \mathrm{kgw}(\mathrm{p}=0.000)$ can significantly reduce the levels of HSP 47 . Rosmarinus officinalis polyphenols can reduce HSP activity 47 . As the result, it can protect cells against the heat and the temperature increase [21]. Flavanoid apigenin is one that efficiently inhibit HSP 90 in pancreatic cancer that inhibit the proliferation and migration of pancreatic cancer cells [22]. Other flavonoids group which can decrease the expression of HSP 90, which stimulates apoptosis of prostate cancer cells are quercetin [23]. Genistein is one of inhibitor tyrosine kinase, which activated inflammation cytokine. Genistein can inhibit inflammation process and reduce levels of HSP 47.

\section{Effect of Genistein on the Levels of Collagen Type IV}

The levels of collagen type IV on STZ group 26.864 $\mathrm{ng} / \mathrm{ml}$ higher than the levels of collagen type IV non diabetic group $10.0060 \mathrm{ng} / \mathrm{ml}$. This suggests that hyperglycemia cause increasing levels of type IV collagen. Hyperglycemic conditions stimulate the formation of extracellular matrix. The pathological changes on glomerular basement membrane initiated differences of glomerular filtration [24].

Study results found the dose of genistein,0.5 $\mathrm{mg} / \mathrm{kgw}(\mathrm{p}=0.000), 1 \mathrm{mg} / \mathrm{kgw}(\mathrm{p}=0.000)$ and 2 $\mathrm{mg} / \mathrm{kgw}(\mathrm{p}=0.000)$ in diabetic rat can reduce levels of type IV collagen significantly. Hyperglycemic conditions stimulate the formation of extracellular matrix. Other research [25] found that the administration of genistein concentrations of $5 \mu \mathrm{mol} / \mathrm{l}$ can inhibit the formation of collagen type IV.

Genistein, an isoflavone in soy can inhibit proliferation and collagen formation through suppression of protein tyrosine kinase. This is a signaling protein that promotes the growth and differentiation of cells. By suppressing the accumulation of growth factors, collagen type IV can be reduced [26]. Genistein may also decrease in renal cell apoptosis and reduce the formation of extracellular matrix such as type IV collagen and laminin in diabetic rats that could protect their kidneys due to the conditions of hyperglycemia [25]. Genistein can reduce collagen type IV with decrease level of HSP 47.

\section{CONCLUSION}

Administration of genistein can reduce levels of HSP 47 and collagen type IV in diabetic rats. Genistein is inhibitor tyrosine kinase and as the result, prevent the inflammation process. Decreasing inflammation cytokine will be continued as lowering fibrosis process on kidney diabetic. Thus, investigating inflammatory cytokine will be a plus.

\section{CONFLICT OF INTEREST}

There were no conflict of interest found among the authors in this work.

\section{ACKNOWLEDGMENTS}

The research supported clinical investigator in Biomedic and Farmacology laboratorium Andalas University Indonesia. 


\section{REFERENCES}

[1] Packham DK, Alves TP, Dwyer JP, Atkins R, De Zeeuw D, Cooper M, Lambers Heerspink HJ. Relative incidence of ESRD versus cardiovascular mortality in proteinuric type 2 diabetes and nephropathy: Results from the DIAMETRIC (Diabetes Mellitus Treatment for Renal Insufficiency Consortium) database. American Journal of Kidney Diseases 2012. http://doi.org/10.1053/j.ajkd.2011.09.017

[2] Choi YE, Ahn SK, Lee WT, Lee JE, Park SH, Yoon BB, Park $\mathrm{KA}$. Soybeans ameliolate diabetic nephropathy in rats. Evidence-Based Complementary and Alternative Medicine 2010. http://doi.org/10.1093/ecam/nen021

[3] Sun Y-M, Su Y, Li J, Wang L-F. Recent advances in understanding the biochemical and molecular mechanism of diabetic nephropathy. Biochemical and Biophysical Research Communications 2013 http://doi.org/10.1016/j.bbrc.2013.02.120

[4] Lim AKH, Tesch GH. Inflammation in diabetic nephropathy. Mediators of Inflammation 2012a. http://doi.org/10.1155/2012/146154

[5] Kanasaki K, Taduri G, Koya D. Diabetic nephropathy: The role of inflammation in fibroblast activation and kidney fibrosis. Frontiers in Endocrinology 2013. http://doi.org/10.3389/fendo.2013.00007

[6] Kashihara N, Haruna Y, Kondeti V, Kanwar Y. Oxidative stress in diabetic nephropathy. Curr Med Chem 2010. Retrieved from http://www.ncbi.nlm.nih.gov/pmc/articles/ PMC3708695/

[7] Elmarakby AA, Sullivan JC. Relationship between oxidative stress and inflammatory cytokines in diabetic nephropathy. Cardiovascular Therapeutics 2012. Retrieved from http:// www.scopus.com/inward/record.url?eid=2-s2.0-84856247093 \&partnerlD=40\&md5=e0770becf40eec08fe6719232730679a

[8] Lech M, Anders HJ. Macrophages and fibrosis: How resident and infiltrating mononuclear phagocytes orchestrate all phases of tissue injury and repair. Biochimica et Biophysica Acta - Molecular Basis of Disease 2013; 1832(7): 989-997. http://doi.org/10.1016/j.bbadis.2012.12.001

[9] Sthaneshwar P, Chan SP. Urinary type IV collagen levels in diabetes mellitus. Malaysian Journal of Pathology 2010; 32(1): 43-47.

[10] Taguchi T, Razzaque MS. The collagen-specific molecular chaperone HSP47: is there a role in fibrosis? Trends in Molecular Medicine 2007; 13(2): 45-53. http://doi.org/10.1016/j.molmed.2006.12.001

[11] Ishihara K, Oyaizu S, Fukuchi Y, Mizunoya W, Segawa K, Takahashi M, Yasumoto K. A soybean peptide isolate diet promotes postprandial carbohydrate oxidation and energy expenditure in type II diabetic mice. The Journal of Nutrition 2003; 133: 752-757.

[12] Taguchi T, Nazneen A, Al-Shihri AA, Turkistani K, Razzaque MS. Heat Shock Protein 47: A Novel Biomarker of Phenotypically Altered Collagen-Producing Cells. Acta Histochemica Et Cytochemica 2011; 44(2): 35-41. http://doi.org/10.1267/ahc.11001

[13] Hu FB, Dam RM Van, Liu S. Diet and risk of Type II diabetes: the role of types of fat and carbohydrate 2001.

[14] Hagiwara S, Iwasaka H, Matsumoto S, Noguchi T. Antisense oligonucleotide inhibition of heat shock protein (HSP) 47 improves bleomycin-induced pulmonary fibrosis in rats. Respiratory Research 2007; 8: 37.

http://doi.org/10.1186/1465-9921-8-37

[15] Shafi S, Tabassum N, Ahmad F. Diabetic nephropathy and herbal medicines $2012 . \quad$ Retrieved from https://www.researchgate.net/publication/216313356_Diabeti c_nephropathy_and_herbal_medicines

[16] Behloul N, Wu G. Genistein: A promising therapeutic agent for obesity and diabetes treatment. European Journal of Pharmacology 2013; 698(1-3): 31-38. http://doi.org/10.1016/j.ejphar.2012.11.013

[17] Yang Z, Kulkarni K, Zhu W, Hu M. Bioavailability and pharmacokinetics of genistein: mechanistic studies on its ADME. Anti-Cancer Agents in Medicinal Chemistry 2012. http://doi.org/10.2174/187152012803833107

[18] Reeves PG. Committee Report AIN-93 Purified Diets for Laboratory Rodents : Final Report of the American Institute of Nutrition Ad Hoc Writing Committee on the Reformulation of the AIN-76A Rodent Diet 1993; 1939-1951.

[19] Qi M-Y, Kai-Chen Liu H-R, Su Y, Yu S-Q. Protective effect of Icariin on the early stage of experimental diabetic nephropathy induced by streptozotocin via modulating transforming growth factor $\beta 1$ and type IV collagen expression in rats. Journal of Ethnopharmacology 2011; 138(3): 731-6. http://doi.org/10.1016/j.jep.2011.10.015

[20] Ohashi S, Abe H, Takahashi T, Yamamoto Y, Takeuchi M, Arai H, Doi T. Advanced Glycation End Products Increase Collagen-specific Chaperone Protein in Mouse Diabetic Nephropathy. Journal of Biological Chemistry 2004; 279(19): 19816-19823. http://doi.org/10.1074/jbc.M310428200

[21] Omri AEL, Han J, Ben Abdrabbah M, Isoda H. Down regulation effect of Rosmarinus officinalis polyphenols on cellular stress proteins in rat pheochromocytoma PC12 cells. Cytotechnology 2012; 64(3): 231-240. http://doi.org/10.1007/s10616-011-9352-y

[22] He J, Ning C, Wang $Y$, Ma T, Huang $H$, Ge $Y$, Jiang $Y$. Natural plant flavonoid apigenin directly disrupts Hsp90/Cdc37 complex and inhibits pancreatic cancer cell growth and migration. Journal of Functional Foods 2015; 18: 10-21.

\section{http://doi.org/10.1016/j.jff.2015.06.052}

[23] Aalinkeel R, Bindukumar B, Reynolds JL, Sykes DE, Supriya D, Chadha KC, Schwartz SA. NIH Public Access. Prostate, The 2010; 68(16): 1773-1789. http://doi.org/10.1002/pros.20845.The

[24] Ha TS, Hong EJ, Ahn EM, Ahn HY. Regulation of type IV collagen? chains of glomerular epithelial cells in diabetic conditions. Journal of Korean Medical Science 2009; 24(5): 837-843.

http://doi.org/10.3346/jkms.2009.24.5.837

[25] Yuan WJ, Jia FY, Meng JZ. Effects of genistein on secretion of extracellular matrix components and transforming growth factor beta in high-glucose-cultured rat mesangial cells. Journal of Artificial Organs 2009.

http://doi.org/10.1007/s10047-009-0479-y

[26] Cao C, Li S, Dai X, Chen Y, Feng Z, Zhao Y, Wu J. Genistein inhibits proliferation and functions of hypertrophic scar fibroblasts - Burns 2009; 35: 89-97. http://doi.org/10.1016/j.burns.2008.03.011

\section{DOI: https://doi.org/10.29169/1927-5951.2018.08.04.2}

(C) 2018 Dafriani et al.; Licensee SET Publisher.

This is an open access article licensed under the terms of the Creative Commons Attribution Non-Commercial License (http://creativecommons.org/licenses/by-nc/3.0/) which permits unrestricted, non-commercial use, distribution and reproduction in any medium, provided the work is properly cited. 